\title{
PELAKSANAAN PRINSIP KEHATI-HATIAN DALAM PROSES PEMBERIAN KREDIT ON LINE
}

\section{Oleh}

\author{
Mas Rara Tri Retno Herryani \\ Fakultas Hukum Universitas Kadiri \\ Jl. Selomangleng No. 1 Kediri \\ Email : masrara@unik-kediri.ac.id
}

\begin{abstract}
Sebagai lembaga keuangan dalam melakukan berbagai macam aktivitas keuangan. Dalam kegiatan usahanya dibidang jasa keuangan, seperti pemberian kredit. Setiap lembaga keuangan diwajibkan untuk memelihara kesehatannya sesuai dengan ketentuanketentuan yang berlaku dan wajib melakukan usaha berdasarkan prinsip kehati-hatian.
\end{abstract}

Kata Kunci : kredit, kehati-hatian

\section{Pendahuluan}

Kebutuhan masyarakat dalam kehidupan sehari-hari sangat beraneka ragam, dan selalu meningkat. Pada sisi lain setiap manusia selalu berusaha untuk memenuhi kebutuhannya, sedangkan kemampuan untuk mencapai sesuatu yang diinginkannya itu terbatas. Hal ini menyebabkan manusia memerlukan bantuan untuk memenuhi hasrat dan cita-citanya. Dalam hal berusaha, untuk meningkatkan usahanya atau untuk meningkatkan daya guna sesuatu barang, memerlukan bantuan dalam bentuk permodalan. Bantuan dari bank dalam bentuk pinjaman modal inilah yang sering disebut dengan kredit.

Pemberian kredit secara on line telah menjadi dalam era revolusi industri ke 4. Proses tersebut cukup dilakukan dengan sarana smartphone maupun laptop yang terhubung dengan internet, masyarakat dapat mengakses informasi produk finansial melalui internet saja. 
Sebelum berlakunya pemberian kredit secara on line, proses pemberian kredit dengan mendatangi bank untuk mendapatkan informasi tentang produk bank tersebut. Pemberian kredit dapat dilaksanakan beberapa langkah, yaitu mencari bank yang bersedia memberian pinjaman, berapa besaran bunga yang ditetapkan tiap-tiap bank juga jangka waktu pinjaman dan besaran angsuran pembayaran.

Informasi tersebut dapat diperoleh secara on line dengan membuka website pemberi kredit, dalam website tersebut akan mendapatkan beragam informasi tentang kredit dan bank pemberi kredit juga informasi-informasi lain yang berkaitan dengan pemberian kredit. Pemberian kredit merupakan kepercayaan bank sebagai pemilik modal kepada debitor sebagai penerima dana. Persyaratan administrasi yang harus dipenuhi dalam kredit, apabila sudah lengkap pengajuannya akan dilanjutkan pencairan kredit untuk persyaratan tersebut setiap bank mempunyai persyaratan yang berbeda-beda.

Pemerintah melalui otoritas keuangan dan perbankan berwenang menetapkan aturan dan tanggung jawab melakukan pengawasan terhadap jalannya usaha tersebut. Oleh karenanya, kebijakan pemerintah disektor keuangan harus diarahkan pada upaya mewujudkan perbankan yang sehat, kuat dan kokoh. Hal ini penting dalam pengembangan infrastruktur keuangan dalam rangka mengatasi kesenjangan antara tabungan dan investasi tetapi juga berperan penting dalam memelihara kestabilan ekonomi makro dan mikro melalui keterkaitannya dengan efektivitas kebijakan moneter. Dasar hukum dari suatu kredit, yaitu:

1. Adanya kesepakatan antara debitur dengan kreditur yang disebut perjanjian kredit;

2. Adanya pihak yaitu kreditur dan debitur;

3. Adanya kesanggupan atau janji untuk membayar hutang;

4. Adanya pinjaman berupa pemberian sejumlah uang;

5. Adanya perbedaan waktu antara pemberian kredit dengan pembayaran kredit. ${ }^{1}$

Unsur - unsur dari pemberian kredit, yaitu :

1. Kepercayaan

2. Waktu suatu masa

3. Prestasi (objek kredit)

\footnotetext{
${ }^{1}$ Faisal Santiago, Pengantar Hukum Bisnis, Jakarta, h. 28
} 


\section{Kehati-hatian. ${ }^{2}$}

Pemberian kredit yang tidak memperhatikan kebijaksanaan dan prosedur yang ada akan mengundang timbulnya penyimpangan-penyimpangan yang lain, semakin jauh pemberian kredit dari pedoman yang telah disusun maka akan semakin besar prosentase kredit macet. Salah satu hal yang paling penting dalam pemberian kredit yaitu dengan melakukan deteksi dini (evaluasi kembali) atas kredit yang diduga akan bermasalah, sehingga kredit tersebut dapat diselamatkan dan terhindar dari kemacetan. Kredit macet merupakan suatu keadaan dimana seseorang nasabah tidak mampu membayar lunas kredit bank beserta bunganya dan tidak tepat waktu apa yang telah diperjanjikan.

Saat semua masalah ini bermunculan, maka secara otomatis akan menghambat kelancaran operasional perusahaan yang harus di capai. Oleh karena itu, sebelum melakukan pemberian kredit perusahaan harus memperhatikan unsur " $5 \mathrm{C}$ " ( the five cof credit ) yaitu character, capacity, capital, collateral, dan condition. Yang dimaksud dengan kredit macet; adalah suatu keadaan dimana seseorang nasabah tidak mampu membayar lunas kredit bank beserta bunganya dan tidak tepat waktu apa yang telah diperjanjikan.

Kredit bermasalah tidak muncul secara tiba-tiba, selalu ada tanda-tanda atau indikasi awal. Satu-satunya alasan debitor tidak mau membayar adalah karena ia tidak punya itikad baik, inilah alasan bank harus sangat berhati-hati memberikan kredit karena waktu yang tersedia untuk mengenal karakter (kemauan untuk membayar), bukan masalah bisnis (kemampuan untuk membayar). Yang sering terjadi adalah manajemen perusahaan tidak peka terhadap berbagai indikasi awal kredit bermasalah yang sering terjadi di perusahaannya, atau, biasa jadi enggan untuk mengakuinya. Meski demikian, biasa juga karena indikasi munculnya kredit bermasalah dapat muncul dari mana saja.

\section{RUMUSAN MASALAH}

Berdasarkan uraian yang telah diuraikan diatas maka permasalahan yang akan dikaji dalam penelitian ini adalah bagaimana pelaksanaan prinsip kehati-hatian dalam proses pemberian kredit on line.

\section{METODE PENELITIAN}

\footnotetext{
${ }^{2}$ Ibid, h. 29
} 
Dalam penelitian ini menggunakan harus menggunakan metode penelitian yang bertujuan untuk menentukan permasalahan. metode penelitian merupakan suatu persyaratan dalam penelitian agar mendapatkan hasil sesuai dengan isu yang dikemukakan. Metode penelitian dalam penelitian ini bertipe yuridis normative.

\section{PEMBAHASAN}

Istilah kredit berasal dari bahasa Yunani "Credere" artinya "kepercayaan" atau dalam bahasa latin "Creditum" berarti kepercayaan akan kebenaran. Oleh karena itu dasar dari kredit adalah kepercayaan. ${ }^{3}$ Pemilik uang atau barang memberi kepercayaan kepada pihak peminjam (debitor) untuk menggunakan uang atau barangnya selama waktu tertentu. Peminjaman ini disertai pula kepercayaan bahwa sang debitur dapat mengembalikan uang atau barang yang dipinjamkan. Dengan demikian kredit adalah pemberian pemakaian suatu uang atau barang kepada orang lain dalam jangka waktu tertentu dengan bunga jaminan atau tanpa bunga jaminan dengan pemberian jasa bunga dan atau tanpa bunga.

Teori kepercayaan (vertrouwenstheorie) mengajarkan bahwa kesepakatan itu terjadi pada saat pernyataan kehendak dianggap layak diterima oleh pihak yang menawarkan. ${ }^{4}$ Maksudnya percaya kepada penerima kredit bahwa kredit yang disalurkannya pasti akan dikembalikan sesuai perjanjian. Sedangkan bagi Penerima kredit merupakan penerimaan kepercayaan sehingga mempunyai kewajiban untuk membayar sesuai jangka waktu.

Menurut R. Subekti yang dimaksud dengan perjanjian adalah : Suatu peristiwa dimana seseorang berjanji kepada orang lain atau dimana dua orang itu saling berjanji untuk melaksanakan sesuatu. ${ }^{5}$ Dalam bahasa Belanda, perjanjian disebut juga overeenkomst dan hukum perjanjian disebut overeenkomstenrech. Hukum perjanjian diatur dalam buku III BW ( KUHPerdata). Pasal 1313 KUH Perdata, perjanjian adalah suatu perbuatan dengan mana satu orang atau lebih mengikatkan dirinya terhadap satu orang atau lebih.

\footnotetext{
${ }^{3}$ Muchdarsyah Sinungan, Dasar-Dasar dan Teknik Managemen Kredit, Bumi Aksara, Jakarta, 1991, h. 159

${ }^{4}$ Mariam Darus Badrulzaman, Sutan Remy Sjahdeini, Heru Soepraptomo, Faturrahman, Taryana Soenandar, Kompilasi Hukum Perikatan, Citra Aditya Bakti, Cet. I, Bandung, 2001, h.75.

${ }^{5}$ R. Subekti, Hukum Perjanjian, Intermasa, Bandung, 1987, h. 9.
} 
Pemberian kredit, prinsip kehati-hatian adalah melakukan analisis yang mendalam untuk memperoleh keyakinan terhadap itikad baik, kemampuan dan kesanggupan calon debitor untuk membayar utangnya kembali. Unsur kepercayaan tidak terbatas pada penerima kredit, tetapi terjaganya kepercayaan akan kejujuran dan kemampuan dalam mengembalikan pinjaman itu tepat pada waktunya. dalam memberikan kredit kepada debitur harus mempunyai kredibilitas atau kelayakan untuk memperoleh kredit.

Pemberian kredit secara on line tidak memerlukan persyaratan sebagaimana yang seharusnya dilakukan dalam ketentuan perbankan. Data yang diberikan cukup sederhana dan proses analisa yang dilaksanakan tidak rumit. Apabila terjadi kredit macet, untuk penyelesaian kredit macet tersebut tidak ada dokumen yang secara fisik telah ditandatangani persetujuan dilakukan secara on line. Penyelesaian yang dilakukan tidak sesuai ketentuan yang telah diatur dalam perbankan.

Perjanjian kredit merupakan perjanjian konsensuil antara debitor dengan kreditor (Bank) yang melahirkan hubungan hutang piutang, dimana debitor berkewajiban membayar kembali pinjaman yang diberikan oleh kreditor, dengan berdasarkan syarat dan kondisi yang telah disepakati oleh para pihak. Dengan demikian hubungan kredit bank berlaku ketentuan dalam Buku III KUH Perdata tentang perikatan.

Sebelum menyetujui permohonan yang diajukan calon debitor untuk mendapatkan fasilitas kredit, maka bank akan melakukan analisis secara yuridis dan ekonomis terhadap calon debitor untuk menentukan kemampuan dan kemauan calon debitor tersebut untuk membayar kembali fasilitas kredit yang akan dinikmatinya sesuai dengan yang telah diperjanjikan.

Aspek yuridis dari suatu perjanjian kredit, yaitu adanya dua pihak yang saling mengikatkan diri. Oleh karena itu analisis secara yuridis yang akan dilakukan oleh bank terhadap calon debitor meliputi analisis terhadap terpenuhinya syarat-syarat sahnya suatu perjanjian yang tercantum dalam Pasal 1320 KUH Perdata, yaitu adanya kesepakatan di antara kedua pihak yaitu pihak bank dengan pihak calon debitor, cakap untuk membuat perjanjian, mengenai suatu hal tertentu dan adanya suatu sebab yang halal.

Aspek ekonomi, dengan menggunakan prinsip yang telah dikenal dalam dunia perbankan sebagai "The Five C'S of credit analisis" terdiri dari character, capital, capacity, collateral dan condition of economic. Produk kredit merupakan sumber 
pendapatan terbesar. Namun disisi lain terdapat resiko tidak kembalinya dana atau kredit yang disalurkan tersebut. Melalui analisis yang mendalam yaitu dengan menerapkan prisip kehati-hatian terhadap setiap permohonan kredit yang diterimanya dan harus melakukan review terhadap setiap pemberian kredit yang disalurkannya.

Prinsip kehati-hatian adalah suatu prinsip yang menegaskan bahwa dalam menjalankan kegiatan usaha baik dalam penghimpunan terutama dalam penyaluran dana kepada masyarakat harus sangat berhati-hati. Tujuan dilakukannya prinsip kehati-hatian ini agar bank selalu dalam keadaan sehat menjalankan usahanya dengan baik dan mematuhi ketentuan-ketentuan dan norma-norma hukum yang berlaku di dunia perbankan. Kegiatan perbankan tidak bisa seluruhnya diserahkan kepada mekanisme pasar, karena kenyataannya pasar tidak selalu mampu membetulkan dirinya sendiri bila terjadi sesuatu diluar dugaan. Kontrol dari Bank Indonesia/OJK terhadap pelaksanaan prinsip kehati-hatian dalam dunia perbankan menjadi salah satu solusi terbaik dalam menjaga dan mempertahankan eksisitensi perbankan, yang pada akhirnya akan menumbuhkan kepercayaan dari masyarakat.

Prinsip kehati-hatian tertera dalam Pasal 2 dan Pasal 29 ayat (2) Undang-Undang Nomor 10 Tahun 1998.

\section{Prinsip Kerahasiaan ( secrecy principle)}

Prinsip kerahasiaan bank diatur dalam Pasal 40 sampai dengan Pasal 47 A UndangUndang Nomor 10 Tahun 1998. Pasal 40, bank wajib merahasiakan keterangan mengenai nasabah penyimpan dan simpanannya. Namun dalam ketentuan tersebut kewajiban merahasiakan itu bukan tanpa pengecualian. Kewajiban merahasiakan itu dikecualikan untuk dalam hal-hal untuk kepentingan pajak, penyelesaian utang piutang bank yang sudah diserahkan kepada badan Urusan Piutang dan Lelang/ Panitia Urusan Piutang Negara (UPLN/PUPN), untuk kepentingan pengadilan perkara pidana, dalam perkara perdata antara bank dengan nasabah, dan dalam rangka tukar menukar informasi antar bank.

\section{Prinsip Mengenal Nasabah ( know how costumer principle )}

Prinsip mengenal nasabah adalah prinsip yang diterapkan oleh bank untuk mengenal dan mengetahui identitas nasabah, memantau kegiatan transaksi nasabah termasuk melaporkan setiap transaksi yang mencurigakan. Prinsip mengenal nasabah nasabah diatur dalam PBI (Peraturan Bank Indonesia) Nomor 5/23/PBI/2003 tentang 
penerapan Prinsip Mengenal Nasabah (Know Your Customer Principles) tentang Penerapan Prinsip Mengenal Nasabah. Tujuan yang hendak dicapai dalam penerapan prinsip mengenal nasabah adalah meningkatkan peran lembaga keuangan dengan berbagai kebijakan dalam menunjang praktik lembaga keuangan, menghindari berbagai kemungkinan lembaga keuangan dijadikan ajang tindak kejahatan dan aktivitas illegal yang dilakukan nasabah, dan melindungi nama baik dan reputasi lembaga keuangan.

Proses pemberian kredit perlu diperhatikan prinsip-prinsip perkreditan yang dikenal dengan 5 (lima) C, atau "The Five C Of Credit Analysis" (Character, Capacity, Capital, Collateral, Condition) :

a. Character (watak)

Kredit : Atas dasar kepercayaan

Kepercayaan: Keyakinan terhadap moral watak dan sifat pribadi yang positif. Character merupakan faktor dominan.

Penilaian character : tingkat kejujuran, integritas dan itikad baik.

Character : tingkat kemauan mengembalikan kredit.

Cara mengetahui:

- Daftar riwayat hidup

- Past performance

b. Capacity (kapasitas)

Penilaian kemampuan pembayaran. Dimana hasil usaha baik yang diperoleh akan mampu membayar kredit. Pengukuran capacity dengan pendekatan :

1. Past Performance : track record usaha

2. Financial : rata-rata neraca dan $\mathrm{R} / \mathrm{L}$

c. Capital (modal)

Modal sendiri yang dimiliki (Self Financing). Semakin besar modal sendiri, semakin besar pula tanggung jawab dan kesungguhannya atau sebaliknya. Besar kecilnya capital: neraca perusahaan (owner equity, laba ditahan dll).

d. Collateral (jaminan)

Barang-barang jaminan yang diserahkan debitur sebagai alat pengamanan apabila usaha gagal. Sifatnya sebagai pelangkap kelayakan usaha.

Bentuk jaminan :

1. Jaminan kebendaan (fisik) 
2. Jaminan tidak berwujud (non fisik)

Nilai jaminan harus lebih besar dari nilai kredit dan aman dari aspek yuridis.

e. Condition of Economic

Analisis terhadap situasi dan kondisi perekonomian yang mempengaruhi terhadap kelancaran usaha. Pengaruh kebijakan-kabijakan pemerintah terhadap perekonomian atau usaha-usaha tertentu.penilaian dilakukan secara makro dan mikro. Bagaimana usaha yang bersangkutan saat ini dan nanti secara prospective dan potensinya.

\section{KESIMPULAN}

Prinsip kehati-hatian yang dikenal dengan 5C atau The Five $C$ Of Credit Analysis. Merupakan salah satu asas penting yang wajib diterapkan atau dilaksanakan oleh bank dalam menjalankan kegiatan usahanya. Prinsip kehati-hatian mengharuskan pihak pemberi kredit untuk selalu berhati-hati dalam menjalankan kegiatan usahanya, dalam arti harus selalu konsisten dalam melaksanakan peraturan perundang-undangan berdasarkan profesionalisme dan itikad baik.

\section{DAFTAR PUSTAKA}

Buku :

Abdulkadir Muhammad, Rilda Murniati, Segi Hukum Lembaga Keuangan Dan Pembiayaan, Bandung, Citra Aditya Bakti, 2004.

Faisal Santiago, Pengantar Hukum Bisnis, Jakarta, 2012.

Mariam Darus Badrulzaman,Sutan Remy Sjahdeini, Heru Soepraptomo, Faturrahman, Taryana Soenandar, Kompilasi Hukum Perikatan, Bandung, Citra Aditya Bakti, Cet. I, 2001.

Muchdarsyah Sinungan, Dasar-Dasar Dan Teknik Managemen Kredit, Jakarta, Bumi Aksara, 1991.

R. Subekti, Hukum Perjanjian, Intermasa, Bandung, 1987.

Thamrin Abdullah, Bank dan Lembaga Keuangan, Jakarta, Raja Grafindo Persada, 2012.

Peraturan Perundang-undangan :

Kitab Undang-undang Hukum Perdata, Bandung, Citra Umbara, 2007. 
Undang-undang Nomor 10 Tahun 1998 Tentang Perubahan Atas Undang- undang Nomor 7 Tahun 1992 Tentang Perbankan.

Undang-undang Nomor 3 Tahun 2004 Tentang Perubahan Atas Nomor 23 Tahun 1999 Tentang Bank Indonesia.

Jurnal :

Heru Supraptomo," Analisis Ekonomi Terhadap Hukum Perbankan" Jurnal Hukum Bisnis, Yayasan Pengembangan Hukum Bisnis, Jakarta, volume 1, 1997. 